\title{
Non-financial reporting in Spain. The effects of the adoption of the 2014 EU Directive
}

\author{
María-Antonia García-Benau ${ }^{\mathrm{a}}$, Helena-María Bollas-Araya ${ }^{\mathrm{b}}$, Laura Sierra-García \\ a) Department of Accounting, Faculty of Economics, University of Valencia, Valencia-SPAIN. \\ b) Department of Economics and Social Sciences, Higher Polytechnic School of Alcoy, Universitat Politècnica de València, Alcoy-SPAIN. \\ c) Department of Financial Economics and Accounting, Faculty of Business, University Pablo de Olavide, Sevilla-SPAIN.
}

\author{
${ }^{c}$ Corresponding author. \\ E-mail address: lnsiegar@upo.es
}

\section{A R T I C L E I N F O}

\section{Article history:}

Received 5 August 2019

Accepted 6 May 2020

Available online 1 January 2022

\section{JEL classification:}

M140

M400

M480

Keywords:

Non-Financial Information

Directive 2014/95/EU

Management Report

Sustainability Report

Spain
A B S T R A C T

The Directive 2014/95/EU imposes new requirements regarding the disclosure of non-financial information (NFI). The aim of this paper is to analyse the NFI disclosed by Spanish listed companies. This is a pioneering study in Spain, since it was conducted during the first year in which NFI disclosure was mandatory, accord ing to the requirements of the Spanish adaptation of Directive. We determine whether decisions on NFI reporting adopted in this respect (i.e. to do so within the management report or as a separate sustainability report) depend on the company's characteristics. In addition, we consider whether the content of such reports differs significantly. Findings show that some Spanish companies do not disclose mandatory NFI. Larger and more profitable companies, which belong to specific sectors and have a sustainability committee, are more likely to disclose this information in a sustainability report. The contents of management and sustainability reports present significant differences.

(C)2022 ASEPUC. Published by EDITUM - Universidad de Murcia. This is an open access article under the CC BY-NC-ND license (http://creativecommons.org/licenses/by-nc-nd/4.0/).

La información no financiera en España. Los efectos de la adopción de la Directiva de la UE de 2014

R E S U M E N

La Directiva 2014/95/UE impone nuevos requisitos en cuanto a la divulgación de información no financiera (IFN). El objetivo de este trabajo es analizar la IFN divulgada por las empresas cotizadas españolas. Se trata de un estudio pionero en España, ya que se realizó durante el primer año en el que la divulgación de IFN era obligatoria, según los requisitos de la adaptación española a la mencionada Directiva. Determinamos si las decisiones sobre la presentación de la información no financiera adoptadas al respecto (es decir, hacerlo dentro del informe de gestión o como un informe de sostenibilidad independiente) dependen de las características de la empresa. Además, estudiamos si el contenido de dichos informes difiere significativamente. Los resultados muestran que algunas empresas españolas no divulgan la información no financiera obligatoria. Las empresas más grandes y rentables, que pertenecen a sectores específicos y que tienen un comité de sostenibilidad, son más propensas a divulgar esta información en un informe de sostenibilidad. Los contenidos de las memorias de gestión y de sostenibilidad presentan diferencias significativas.

(C2022 ASEPUC. Publicado por EDITUM - Universidad de Murcia. Este es un artículo Open Access bajo la licencia CC BY-NC-ND (http://creativecommons.org/licenses/by-nc-nd/4.0/). 


\section{Introduction}

The European Union gave a strong impulse to the disclosure of non-financial and diversity information with the promulgation of Directive 2014/95/EU of the European Parliament and the Council (EU, 2014a) ${ }^{1}$. This EU initiative is significant for three main reasons. Firstly, it contributes to corporate information transparency, highlighting the impact of organisations' activities in areas such as the environment, society, corruption and human rights (Yu, 2008; Husted, 2015). Secondly, the requirement to publish non-financial and diversity information produces a strategic effect by improving organisations' communication with their stakeholders (Fonseca, 2010; Miska et al., 2013; Maroun, 2017). Finally, the company's analysis of its impact on society and its identification of the risks to sustainability, when appropriately acted upon, can make a significant contribution to long-term economic growth (Kolk, 2003; Morhardt, 2010; Spanish Ministry of Employment and Social Security, 2014).

Directive 2014/95/EU imposes new requirements regarding the disclosure of non-financial information (NFI) and of information on diversity. It applies to Public Interest Entities (PIEs) with more than 500 employees, which according to the Commission means it will affect around 6,000 companies and business groups (EU, 2014b). In this paper, we analyse only the question of compliance with the NFI aspect of the Directive, but it should be noted that a description of the organisation's diversity policy is required to be published in the corporate governance statement.

According to this Directive, PIEs must publish a "Nonfinancial statement". One of the most interesting points of the Directive is the mandatory publication of NFI either within the management report or within a separate report. In other words, the Directive stipulates the NFI that companies must publish but does not specify the report in which it should be disclosed or require a standard publication format. We believe it is important to examine why companies decide to include this information in one report or the other, in order to establish the communication strategies followed, taking into account both purely financial issues and aspects related to the way in which NFI is presented. Exploring the communication of NFI could help us to understand how companies use corporate documents to communicate with stakeholders in a transparent manner (Merkl-Davies \& Brennan, 2017). Accordingly, this empirical study focuses on the different types of reports in which companies publish the NFI required by Directive 2014/95/EU, and the scope of this publication, seeking to highlight the crucial role played by communication strategies in informing stakeholders (Matsumoto et al., 2011; Brennan et al., 2013). The wide range of stakeholders involved can make that presenting the information was a complex process, requiring careful definition of issues such as the volume of information provided and the graphics and images to be included.

Spain is an interesting case for study because Spanish companies achieve high scores in various sustainability indexes (García-Sánchez et al., 2011; KPMG, 2011; KPMG, 2015; Garrido-Miralles et al., 2016; Ortiz \& Marín, 2017; Tarquinio et al., 2018; Sierra-García et al., 2018). According to KPMG (2015), 85\% of the Spanish companies analysed published sustainability reports, in comparison to the global average of $73 \%$. Considering these considerations, we believe it is useful to examine how Spanish listed companies provide this information and to detail their communication strategies.

${ }^{1}$ This Directive modifies Directive 2013/34/EU.
In brief, the aim of this paper is to analyse the NFI disclosed by Spanish listed companies and their reporting strategies, focusing on the first NFI reports disclosed in Spain in accordance with the requirements of the Spanish adaptation of the Directive 2014/95/EU. These reports, which refer to December 2017 and were made available from early 2018, provide information on business policies regarding the disclosure of NFI. As part of our analysis of communication strategies, we examined whether companies disclosed NFI as part of the management report (MR) or within a separate sustainability report (SR). According to legitimacy theory, the means of communication employed for information disclosure is determined, at least in part, by the nature of the message (Branco \& Rodrigues, 2008). In the present case, one of the purposes of the communication is to help legitimise the company's actions before its stakeholders (Nurunnabi et al., 2011; Rodríguez-Gutiérrez et al., 2013). Furthermore, we analysed differences between MRs and SRs in terms of length, tables, graphics, photos and infographics.

The results obtained from this empirical study, performed using logistic and multilogistic regressions, show that some Spanish companies do not disclose NFI and the likelihood of disclosing NFI is higher among larger companies that operate in specific sectors. Larger companies, belonging to a specific sector, and which have a sustainability committee, are more likely to disclose NFI in a SR. On the other hand, companies that are more profitable are more likely to reveal NFI in the MR. The contents of MRs and SRs present significant differences regarding document length, tables, graphics, photos and infographics.

The rest of this paper is structured as follows. After this introduction, we describe the context of this research. The following sections present an empirical study, showing the hypotheses proposed, the sample considered, and the method applied. The next section shows the results of our empirical study. The final section presents the main conclusions drawn.

\section{Research context}

The first major EU initiative to promote the disclosure of NFI was Directive 2003/51/EU (2003), which emphasised the need to analyse environmental and social aspects of business performance to clarify companies' development, performance and position. In 2011, another important expansion of NFI reporting in Europe took place with the publication of the Communication on the Single Market Act (EU, 2011), which referred to investors' need for more information with respect to social and environmental corporate information. Nevertheless, companies located in EU Member States still provided most of the non-financial and diversity information voluntarily (Wyatt \& Frick, 2010; EU, 2011; Ortiz \& Marín, 2014; KPMG, 2017).

Perhaps the most important step taken in Europe to advance the disclosure of NFI in corporate reporting was the publication of EU Directive 2014/95/EU (EU, 2014). This document focused on the reporting of impacts and risks, and required all large PIEs to publish a non-financial statement with information relevant to the environment, society, measures to combat corruption and bribery, labour issues, human rights and diversity. In each of these areas, the PIE should describe the policy pursued, its outcomes (including due diligence processes implemented), the most important sustainability-related risks identified, and key performance indicators.

The new rules and requirements promote transparency and are in line with international best practices of corpor- 
ate reporting. The disclosure items stipulated in Directive 2014/95/EU are in line with Global Reporting Initiative (GRI) standards, which place a strong emphasis on the concept of materiality, to ensure that stakeholders play a significant role in assessing this question.

Directive 2014/95/EU demands that PIEs publish a "Nonfinancial statement", addressing the following areas: environmental and social issues, employment, respect for human rights and measures to combat corruption and bribery (Arts. 19a and 29a). This NFI reveals the sustainability risks facing a company, and its communication is expected to enhance confidence among stakeholders, as well as benefiting corporate performance (Hernández, 2017). According to the Directive, these elements should be presented in the management statement or elsewhere, and if not provided, the reasons for this should be explained. In 2017, the European Commission published a Communication providing guidelines on the presentation of high-quality NFI (Brammer \& Pavelin, 2008; EU, 2017), setting out the following key principles: the material disclosed must be fair, balanced and understandable; comprehensive but concise; strategic and forward looking; stakeholder-orientated; and consistent and coherent. Moreover, according to Directive 2014/95/EU, international recommendations in this respect, such as the UN Guiding Principles on Business and Human Rights, ISO 26000, the OECD Guidelines for Multinational Enterprises, the Global Reporting Initiative and EU Eco-Management and Audit Scheme, should be followed.

Under EU rules, Directive 2014/95/EU should have been transposed into the national legislation of the Member States by 6 December 2016, so that European companies would publish their first non-financial reports referring to the financial year starting in 2017. However, the Directive was transposed into Spanish law by Royal Decree-Law 18/2017 of 24 November 2017, that is, almost one year after the stipulated deadline. Consequently, Spanish companies have only published the new EU requirements since 2018 (referring to the information available at 31 December 2017). The Directive required PIEs, public limited companies and private limited companies, in every case employing at least 500 workers, to provide the necessary information. In general terms, the Spanish adaptation is in line with the provisions of the EU Directive, and contains no additional requirements (Hernández, 2017).

However, although this paper is focused on Royal DecreeLaw $18 / 2017$ of 24 November 2017, it is important to point out that in late 2018, new legislation was passed (Act $11 / 2018$, published in the Spanish Official Gazette on 29 December 2018), requiring the provision of new information on non-financial issues and on diversity. This Act amended the Code of Commerce, Corporation Law and Audit Law, and produced major changes in how Spanish companies operate. It came into force on the day after publication (i.e. 30 December 2018) and therefore affected the data for the fiscal year starting 1 January 2018, which are reported from the start of 2019. The impact of these changes will also be felt beyond Spain's borders, since they impose new requirements concerning NFI disclosure and constitute a benchmark in European legislation in this respect. Specifically, the Act expands the scope of regulatory requirements, affecting all companies with more than 250 employees. It imposes mandatory external assurance by an independent provider. It broadens the content to be reported to include tax payments and issues of diversity related to the wage gap. Finally, it obliges companies to disclose NFI online within six months of year-end and to maintain its availability for five years. These NFI dis- closure strategies currently followed by Spanish companies foreshadow the changes soon to be adopted in line with the requirements of the EU Directive.

Before the EU Directive was adopted, some legislative initiatives were taken in Spain to foster the disclosure of NFI, but with little success (Archel et al., 2011). For example, Sustainable Economy Act 2/2011 (2011) was intended to achieve a significant advance in the field of sustainability (Luque-Vilchez \& Larrinaga, 2016) but little real implementation was achieved. Nevertheless, in response to stakeholders' demands, there has been some progress in the provision of information on the impact of corporate activities (Moneva \& Llena, 1996; Moser \& Martin, 2012). Thus, in 2014, the Ministry of Employment and Social Security approved the "Spanish Strategy on Corporate Social Responsibility Practices 2014-2010" aimed at promoting responsible practices in companies and in public agencies. This Strategy document recommended compliance with the OECD (2011) guidelines for multinational enterprises.

\section{Theoretical background and literature review}

Although the question of corporate social responsibility (CSR) has aroused great interest in recent years (Muttakin \& Khan, 2014), significant heterogeneity remains in the way in which companies publish NFI (Fathi, 2013). Nevertheless, in most cases, they provide this information in a document termed "Sustainability Report" (Davis \& Searcy, 2010; Mio \& Venturelli, 2013; Muhammad et al., 2013).

It has been argued that the communication of NFI helps develop an equitable relationship between the company and its stakeholders (Coombs \& Holladay, 2012). However, according to Ali et al. (2017), who conducted a literature review of the determinants of sustainability disclosure, there is no generally accepted theory in this respect. Most of the studies considered use a specific theory or a combination of theories to explain the determinants/motivations of sustainability disclosure (de Villiers \& van Staden, 2011; de Klerk \& de Villiers, 2012; Cho et al., 2015). In our opinion, the strategic behaviour of companies with regard to questions of sustainability could be accounted for in the context of standard approaches such as legitimacy theory or stakeholder theory. The last one was introduced by Freeman (1984), who argued that companies bear a responsibility towards a wide range of stakeholders, not just those traditionally considered. In this respect, May (2011) and Bartlett \& Devin (2011) developed approaches to explain how and why companies communicate with their stakeholders, observing that most companies wish to demonstrate their commitment to sustainability and other social values related to stakeholders' interests. An alternative approach is to address the question of corporate communication as a quest for legitimacy (Deegan, 2002; Lanis \& Richardson, 2012). According to legitimacy theory, a company generates a nexus of contracts, which align corporate values with those of society (Archel et al., 2009). Thus, an organisation might perform sustainability-oriented activities in order to retain or acquire legitimacy (Fernando \& Lawrence, 2014) or to obtain and maintain its resources (Oliver, 1991).

Various studies have analysed the communication of NFI (Lim \& Greenwood, 2017; Kollat \& Farache, 2017). In this respect, Morsing \& Schultz (2006) presented interesting theoretical advances, identifying three types of communication strategies that companies use with their stakeholders: "oneway symmetric", "two-way asymmetric" and "two-way symmetric" (Block et al., 2015; Liao et al., 2017; Hossain et al., 2018). Subsequently, Ziek (2009) added empirical research 
to this theoretical foundation, in order "to make sense of corporate social responsibility communication".

In the present paper, we focus on the first of these strategies, also termed the stakeholder information strategy, choosing not to discuss communication in terms of dialogue with stakeholders, since the information available for analysis is still very recent and there has been little or no response from stakeholders yet. However, some interesting papers have been published in this area, suggesting possibilities for future research (Dhanesh, 2015; Investis, 2015; Yang \& Liu, 2017; Correa et al., 2018; Suárez-Rico et al., 2018).

Evidently, the information needs of different stakeholders are not the same. Thus, certain stakeholder groups will be particularly interested in specific types of NFI. Acknowledging this reality, annual reports are usually intended for investors, sustainability/CSR reports address the broader public, integrated reports are of particular interest to shareholders and combined reports target issues considered relevant to employees (see Dawkins, 2004).

The transposition of Directive 2014/95/EU to the context of each EU Member State provides a useful opportunity to examine the strategies adopted in different countries regarding their commitment to sustainability. Nevertheless, despite the relevance and timeliness of this topic, very few research studies have analysed the impact of the Directive's requirements on European companies to date. Among them, Venturelli et al. (2017) focused on Italian companies to analyse the level of NFI and diversity disclosure, and concluded that an important information gap remains to be addressed, even among large entities. Matuszak \& Rozanska (2017) focused in Polish listed companies to investigate the extent and quality of CSR reporting, and observed that companies are still not compliant with the EU requirements and put little emphasis on information regarding human rights and anti-corruption measures. Sierra-García et al. (2018) focused on the Spanish IBEX-35 index (the benchmark stock market index in Spain), and found that the business sector in which companies operate largely determines their level of regulatory compliance. Mion \& Loza (2019) conducted a content analysis of the sustainability reporting practices of Italian and German companies in the top lists of stock exchanges and demonstrated that the quality of sustainability reporting increased after implementation of the Directive. They also found that obligation of non-financial disclosure, company size and industry type affected sustainability reporting quality. Tiron et al. (2019) focused on Romanian companies and evidenced a slight increasing in NFI disclosure, after the entry into force of the Directive. Their results also showed that the size of the company, its performance and the industry sector in which it operates are the main factors influencing the level of disclosure. Aureli et al. (2020) compared the transposition of Directive among several countries and showed that despite their common points; in some instances, such convergence was just apparent.

\subsection{Development of hypotheses}

The Directive 2014/95/EU required European companies to publish non-financial information. This is a pioneering study in analysing what factors influence NFI reporting since it is mandatory in Spain. As far as we know, only Mion \& Loza (2019) focusing on Italian and German companies and Tiron et al. (2019) focusing on Romanian companies developed similar works in a mandatory context. Nonetheless, previous works have studied what factors influence voluntary CSR/sustainability reporting.
One of the most analysed factors is industry. Numerous studies have reported that the business sector in which a company operates is significantly associated with its level of social and environmental information disclosure (Fernandez-Feijoo et al., 2014; Fortanier et al., 2011; Kolk \& Perego, 2010; among others). According to the legitimacy theory, companies operating in sensitive business sectors, that is, with high social and/or environmental impacts, are more visible to the public and, consequently, they have a greater need to demonstrate that they are socially responsible and to legitimise their role in society (Fernandez-Feijoo et al., 2015). As consequence, they often publish more detailed NFI (Simnett et al., 2009). According to the stakeholder theory, companies from different sectors report on CSR in accordance to their stakeholders' expectations (Sweeney \& Coughlan 2008; Reverte 2009). Thus, levels of stakeholder pressure in this respect determines the degree of NFI disclosure (Brammer \& Pavelin, 2008; Fortanier et al., 2011).

Previous research works also considered listing status as a determinant to disclose NFI (Haniffa \& Cooke, 2005). In line with legitimacy theory, publicly listed companies can be more actively engaged in sustainability practices in order to obey to certain regulations, adopt good practice by competitors, and/or to accomplish with stakeholder pressure (Dowling \& Pfeffer, 1975).

We took into account that, in line with the legitimacy theory, the existence of a sustainability committee could increase the control to mitigate social and environmental risks and to manage perception of firms' NFI practice (Rodrigue et al., 2013; Kend, 2015; Law Chapple et al., 2017; Merkl-Davies \& Brennan, 2017).

We also considered the use of the GRI framework, since it is the most used standard to prepare sustainability reports. According to KPMG (2017), 74\% of the Global 250 companies follow GRI. From the point of view of the stakeholder theory, the presence of the dominant shareholder is positively associated with the adoption of the GRI guidelines (Prado-Lorenzo et al., 2009).

Moreover, we took into consideration assurance given that, in some countries, it is required in order to enhance the reliability and credibility of the information presented (Simnett et al., 2009; Kolk \& Perego, 2010; Mock et al., 2013; Junior et al., 2014; De Beelde \& Tuybens, 2015). Assurance corroborates the quality of the information disclosed (AccountAbility, 2008a, 2008b, 2011; Manetti \& Becatti, 2009; IAASB, 2013; Cho et al., 2014; GRI, 2014; Gürtürk \& Hahn, 2016; Boiral et al., 2019). The assurance process has an important role in establishing legitimacy (O'Dwyer et al., 2011), and it is a necessary tool for satisfying the social demands that ensure the survival of an organisation (Martínez-Ferrero \& GarcíaSánchez, 2017).

Other determinant of information disclosure generally taken is company size (Patten, 2002). According to the legitimacy theory, large companies have a higher political visibility, so they are expected to engage more heavily in a legitimating behaviour (Dowling \& Pfeffer, 1975). From the stakeholder theory perspective, larger companies are subject to greater pressure from stakeholders; hence, they are expected to report more fully on non-financial issues in order to meet users' needs. Moreover, most own higher-grade information systems, which ease information disclosure and creation of corporate reports (Tagesson et al., 2009; Melis et al., 2015).

Research often assumes a positive relation between ROA and NFI disclosure, because companies that are more profitable are more likely to face NFI costs and consequences of disclosing possibly damaging information (Cormier \& Mag- 
nan, 2003; Haniffa \& Cooke, 2005; Kent \& Monem, 2008). According to Haniffa \& Cooke (2005), profitable companies disclose social information to show their contribution to society's well-being and, thus, legitimise their existence. On the contrary, a high level of leverage makes it difficult for companies to face these costs and consequences (Cormier \& Magnan, 2003; Stanny \& Ely, 2008). However, Haniffa \& Cooke (2005) argued that high leveraged companies should disclose more information to legitimise their actions toward creditors and shareholders.

Finally, we considered the measure of liquidity, as an indicator of risk, which is calculated by current ratio, which assess a firmt's ability to redeem current liabilities (Kim \& Im, 2017). Some researchers (Khan, 2010; Kamil \& Herusetya, 2012) found a positive association between liquidity and CSR reporting. According to stakeholder theory, companies with greater liquidity are more likeable for investors, and therefore, they would reveal more non-financial information to attract investors (Gantyowati \& Agustine, 2017). Thus, those companies that have a higher ratio offer more legitimacy.

Furthermore, we examined in detail how companies present their NFI in each case (MRs and SRs). According to stakeholder theory perspective, companies face different stakeholders. Therefore, considering the stakeholder information strategy, diverse types of reports address different stakeholders. Some papers have analysed self-presentation and identity management through selected items (photos, graphs etc.) (Litt et al., 2014; Young \& Quan-Haase, 2013). In this line, we analyse the specific form of self-presentation about NFI by examining length, tables, graphs, photos and infographics contain in the NFI report.

Accordingly, we addressed the following hypotheses:

$\mathrm{H}_{1}$ : The decision to disclose NFI is associated with the company's characteristics (Industry, IBEX-35, Sustainability Committee, Size, Leverage, ROA, Current Ratio).

$\mathrm{H}_{2}$ : The way in which NFI is presented (in a MR or a $S R$ ) is associated with the company's characteristics (Industry, IBEX-35, Sustainability Committee, GRI, Assurance, Size, Leverage, ROA, Current Ratio).

$\mathrm{H}_{3}$ : MRs and SRs present significant differences in terms of length, tables, graphs, photos and infographics.

\section{Methods}

\subsection{Sample description}

This paper analyses Spanish companies' compliance with the requirements of Directive 2014/95/EU with respect to non-financial reporting. In this study, we focus on the companies listed on the Madrid Stock Exchange at June 2018, using their 2017 non-financial reports, issued in 2018. By analysing corporate communication strategies, we also determine whether companies disclose NFI as part of the MR or within a SR.

To test the study hypotheses, we considered four different samples (Table 1). The initial observation identified 130 companies but six were foreign-based and hence we excluded them from the analysis. Thus, sample 1 consisted of $124 \mathrm{com}-$ panies. Sample 2 was composed of the 104 companies that issued non-financial reports. Finally, sample 3 contained the 79 companies that provided NFI in a MR, whereas sample 4 included the 54 companies that issued NFI in a SR.
Table 1. Definition of Variables

\begin{tabular}{|c|c|c|c|c|}
\hline & Sample 1 & Sample 2 & Sample 3 & Sample 4 \\
\hline $\begin{array}{l}\text { Madrid Stock Exchange } \\
\text { at June } 2018\end{array}$ & 130 & 130 & 130 & 130 \\
\hline Less foreign companies & 6 & 6 & 6 & 6 \\
\hline Companies without NFI & - & 20 & 20 & 20 \\
\hline $\begin{array}{l}\text { Companies without NFI } \\
\text { in the management re- } \\
\text { port }\end{array}$ & - & - & 25 & - \\
\hline $\begin{array}{l}\text { Companies without NFI } \\
\text { in a sustainability report }\end{array}$ & - & - & - & 50 \\
\hline Total & 124 & 104 & 79 & 54 \\
\hline
\end{tabular}

As shown in Table 2, 79 companies disclosed NFI in a MR, 54 in a SR, and 29 in both reports. On the other hand, 20 companies did not report NFI, failing thus to comply with the Directive.

Table 2. Definition of Variables

\begin{tabular}{lccccc}
\hline & \multicolumn{4}{c}{ Sustainability Report } \\
& & Yes & No & Total \\
\hline \multirow{2}{*}{ Management Report } & Yes & 29 & 50 & 79 \\
& No & 25 & 20 & 45 \\
\hline Total & & 54 & 70 & 124 \\
\hline
\end{tabular}

Table 3 describes, by sector, the companies that reported NFI. Among those doing so by means of the MR, 25 were in the basic material, industry or construction sectors. Among companies that revealed NFI in a SR, 13 were in financial services or real estate sectors.

Table 3. Management Report vs. Sustainability Report by sector

\begin{tabular}{|c|c|c|c|c|c|c|}
\hline & MR & $\%$ & Total & SR & $\%$ & Total \\
\hline Consumer goods & 17 & 60.71 & 28 & 11 & 39.28 & 28 \\
\hline $\begin{array}{l}\text { Basic materials, industry } \\
\text { and construction }\end{array}$ & 25 & 80.64 & 31 & 11 & 35.48 & 31 \\
\hline Petroleum and energy & 3 & 33.33 & 9 & 6 & 66.66 & 9 \\
\hline Consumer services & 13 & 65.00 & 20 & 10 & 50.00 & 20 \\
\hline $\begin{array}{l}\text { Financial services and } \\
\text { real estate }\end{array}$ & 12 & 55.55 & 27 & 13 & 48.15 & 27 \\
\hline $\begin{array}{l}\text { Technology and telecom- } \\
\text { munications }\end{array}$ & 7 & 77.78 & 9 & 3 & 33.33 & 9 \\
\hline Total & 79 & 63.70 & 124 & 54 & 43.55 & 124 \\
\hline
\end{tabular}
Madrid Stock Exchange.

\subsection{Models}

In order to test the hypotheses 1 and 2, we formulated the following models. Thus, we applied the first model over the sample 1 to analyse whether the decision to disclose NFI depends on company's characteristics. Meanwhile, we applies the second model over the sample 2 to analyse whether the way in which NFI is presented (in a MR or a SR) depends on company's characteristics.

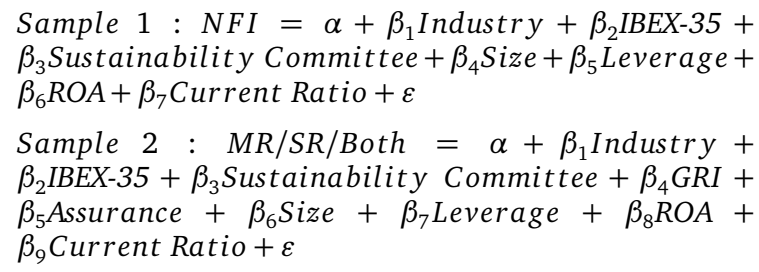

Furthermore, to test the hypothesis 3 , we applied the Mann-Whitney-U test and the Kruskal-Wallis test over the samples 3 and 4 to analyse whether MRs and SRs present significant differences. 


\subsection{Variables}

According to the hypotheses 1 and 2, we considered the dependent variables NFI and MR/SR/Both. As independent variables, we took into account INDUSTRY, IBEX-35, SUSTAINABILITY COMMITTEE, GRI and ASSURANCE. Moreover, we add SIZE, LEVERAGE, ROA and CURRENT RATIO as control variables. In line with the hypothesis 3 , we took into consideration the dependent variables PAGES, PHOTOS, GRAPHS, TABLES and INFOGRAPHICS. All variables are defined in Table 4.

Table 4. Definition of Variables

\begin{tabular}{|c|c|}
\hline VARIABLES & MEASUREMENTS \\
\hline NFI & $\begin{array}{l}\text { A dichotomous variable that takes the value } 1 \text { if the com- } \\
\text { pany disclosed NFI and } 0 \text {, otherwise. }\end{array}$ \\
\hline MR/ SR/ Both & $\begin{array}{l}\text { A categorical variable that takes the value } 1 \text { if the com- } \\
\text { pany disclosed NFI in the management report, the value } \\
2 \text {, if it did so in a sustainability report (CSR, integrated or } \\
\text { annual report), and the value } 3 \text {, if it did so in both. }\end{array}$ \\
\hline Industry & $\begin{array}{l}\text { A categorical variable that reflects the business sector, tak- } \\
\text { ing the value } 1 \text { if the company belongs to the consumer } \\
\text { services sector, } 2 \text { for basic materials, industry and con- } \\
\text { struction, } 3 \text { for consumer goods, } 4 \text { for petroleum and en- } \\
\text { ergy, } 5 \text { for financial and real estate, and } 6 \text { for technology } \\
\text { and telecommunications. }\end{array}$ \\
\hline Ibex-35 & $\begin{array}{l}\text { A dichotomous variable that takes the value } 1 \text { if the com- } \\
\text { pany forms part of the IBEX- } 35 \text { and } 0 \text {, otherwise. }\end{array}$ \\
\hline $\begin{array}{l}\text { Sustainability } \\
\text { committee }\end{array}$ & $\begin{array}{l}\text { A dichotomous variable that takes the value } 1 \text { if the com- } \\
\text { pany has a sustainability committee or similar and } 0 \text {, oth- } \\
\text { erwise. }\end{array}$ \\
\hline GRI & $\begin{array}{l}\text { A dichotomous variable that takes the value } 1 \text { if the com- } \\
\text { pany follows GRI standards and } 0 \text {, otherwise. }\end{array}$ \\
\hline Assurance & $\begin{array}{l}\text { A dichotomous variable that takes the value } 1 \text { if the com- } \\
\text { pany assured the NFI and } 0 \text {, otherwise. }\end{array}$ \\
\hline Size & Natural log of total assets. \\
\hline Leverage & Total debt divided by equity. \\
\hline ROA & Profit divided by total assets. \\
\hline Current ratio & Total current assets to total current liabilities. \\
\hline Pages & Number of pages in the MR and in the SR. \\
\hline Photos & Number of photos in the MR and in the SR. \\
\hline Graphs & Number of graphs in the MR and in the SR. \\
\hline Tables & Number of tables in the MR and in the SR. \\
\hline Infographics & Number of infographics in the MR and in the SR. \\
\hline
\end{tabular}

\section{Results}

\subsection{Descriptive statistics}

Table 5 shows the descriptive statistics for the continuous variables considered. The average company size was 14.34 (natural logarithm of total assets). The mean asset value was 24.9 billion euros, with individual values ranging from 2 million to 690 billion euros. The average ROA was $6.8 \%$ and the minimum value was $-35.7 \%$. The mean leverage was .680 and individual values ranged from .060 to 1.58 . Finally, the mean current ratio was 2.12 with a minimum of .451 and a maximum of 31.01 .
Table 5. Descriptive - Continuous Variables

\begin{tabular}{lcccc}
\hline Variable & Mean & $\begin{array}{c}\text { Standard } \\
\text { deviation }\end{array}$ & Min & Max \\
\hline Size (Ln assets) & 14.34 & 2.41 & 7.98 & 20.35 \\
Assets (million $€$ ) & 24,900 & 87,500 & 2 & 690,000 \\
ROA & .068 & .266 & -.357 & 2.58 \\
Leverage & .680 & .313 & .060 & 1.88 \\
Current ratio & 2.12 & 3.72 & .451 & 31.01 \\
\hline
\end{tabular}

N: 124

Table 6 shows the descriptive results obtained for the dummy variables. By industry, $28.85 \%$ of the companies belonged to the basic material, industry or construction sectors, followed in importance by consumer services $(20.19 \%)$ and financial services and real estate (19.23\%). The sector with the fewest companies in our sample was that of technology and telecommunication (7.69\%). The IBEX-35 contained $33.65 \%$ of the companies in our sample. Only $18.27 \%$ of the companies in the sample had a sustainability committee. On the other hand, over 65\% applied the GRI standard and almost $40 \%$ assured their NFI.

Table 6. Descriptive - Dummy Variables

\begin{tabular}{lccc}
\hline Variables & & & \\
Industry & Freq. & $\%$ & Cum. \\
\hline Consumer Goods & 21 & 20.19 & 20.19 \\
Basic materials, Industry and Construction & 30 & 28.85 & 49.04 \\
Petroleum and Energy & 8 & 7.69 & 56.73 \\
Consumer Services & 17 & 16.35 & 73.08 \\
Financial Services and Real Estate & 20 & 19.23 & 92.31 \\
Technology and Telecommunications & 8 & 7.69 & 100 \\
IBEX-35 & Freq. & $\%$ & Cum. \\
Yes & 35 & 33.65 & 33.65 \\
No & 69 & 66.35 & 100 \\
Sustainability Committee & Freq. & $\%$ & Cum. \\
Yes & 19 & 18.27 & 18.27 \\
No & 84 & 81.73 & 100 \\
GRI & Freq. & $\%$ & Cum. \\
Yes & 68 & 65.38 & 65.38 \\
No & 36 & 34.62 & 100 \\
Assurance & Freq. & $\%$ & Cum. \\
Yes & 41 & 39.42 & 39.42 \\
No & 63 & 60.58 & 100 \\
\hline Total & 104 & 100 & - \\
\hline & & &
\end{tabular}

Table 7 shows the average length of the MRs and SRs published, with 51 and 110 pages, respectively. However, there is a high level of variability within these mean values: the documents contain among 5 and 521 pages, and among 8 and 444 pages, respectively. On average, there are 3.87 photos in each MR, but the minimum is 0 and the maximum, 98. In the SRs, the average is much higher, 35.37 photos, and the maximum number, 153. The content of graphics, tables and infographics is also higher in the SRs than in the MRs.

Table 7. Descriptive - Continuous Variables

\begin{tabular}{|c|c|c|c|c|c|c|c|c|}
\hline \multirow[b]{2}{*}{ Variables } & \multicolumn{4}{|c|}{ Management Report. N: 79} & \multicolumn{4}{|c|}{ Sustainability Report. N: 54} \\
\hline & Mean & S.D. & Min & Max & Mean & S.D. & Min & $\operatorname{Max}$ \\
\hline Pages & 51.99 & 67.67 & 5 & 521 & 110.53 & 90.87 & 8 & 444 \\
\hline Pages (Ln) & 3.546 & .8481 & 1.61 & 6.25 & 4.416 & .7828 & 2.08 & 6.09 \\
\hline Photos & 3.87 & 15.01 & 0 & 98 & 35.37 & 37.77 & 0 & 153 \\
\hline Graphics & 8.27 & 19.10 & 0 & 128 & 20.07 & 19.59 & 0 & 101 \\
\hline Tables & 18.16 & 34.71 & 0 & 220 & 37.70 & 38.49 & 0 & 220 \\
\hline Infographics & 2.91 & 7.30 & 0 & 38 & 9.94 & 14.05 & 0 & 60 \\
\hline
\end{tabular}




\subsection{Empirical results}

Table 8 shows the logistic regression results obtained, in which the dependent variable is whether the company published NFI. The model is statistically significant, with Prob $>\mathrm{chi}^{2}=0.000$. The pseudo $\mathrm{R}^{2}$ is 0.5374 . NFI disclosure is positively related to the financial services and real estate industries ( $\beta$ : $0.2747298, \mathrm{P}>\mathrm{z}: 0.007)$ compared to con- sumer services industry. Furthermore, the size variable is significantly and positively related to the disclosure of NFI $(\beta$ : 1.518126, $\mathrm{P}>\mathrm{z}$ : 0.000). In summary, larger companies and those operating in the financial services and real estate sectors are the most likely to disclose NFI.

Table 9 shows the results obtained for the multinomial logit model, in which the dependent variables are the compan-

Table 8. Logistic Regression. Dependent variable: NFI

\begin{tabular}{|c|c|c|c|c|c|c|}
\hline Variables & Coef. & Std. Err. & $\mathrm{z}$ & $\mathrm{P}>\mathrm{Z}$ & \multicolumn{2}{|c|}{ [95\% Conf. Interval] } \\
\hline \multicolumn{7}{|l|}{ Industry (Reference: Consumer Services) } \\
\hline Basic materials, Industry and Const. & 1.948062 & 1.256722 & 1.55 & 0.121 & -.5150683 & 4.411193 \\
\hline Petroleum and Energy & -1.458862 & 1.558801 & -0.94 & 0.349 & -4.514055 & 1.596331 \\
\hline Consumer Services & .2747298 & 1.43879 & 0.19 & 0.849 & -2.545247 & 3.094707 \\
\hline Financial Services and Real Estate & 3.182715 & 1.173231 & -2.71 & $0.007^{*}$ & -5.482207 & -.8832243 \\
\hline Technology and Telecommunications & -.7765997 & 1.519873 & -0.51 & 0.609 & -3.755496 & 2.202296 \\
\hline Sustainability Committee & -.4917843 & 1.595064 & -0.31 & 0.758 & -3.618052 & 2.634484 \\
\hline Size & 1.518126 & .3980677 & 3.81 & $0.000^{*}$ & .7379282 & 2.298325 \\
\hline ROA & .3658621 & 14.824 & 0.25 & 0.805 & -2.539588 & 3.271312 \\
\hline Leverage & -.8059068 & 1.958835 & -0.41 & 0.681 & -4.645152 & 3.033338 \\
\hline Current Ratio & .1267389 & .3974681 & 0.32 & 0.750 & -.6522843 & .905762 \\
\hline \multicolumn{7}{|l|}{$* 1 \%$} \\
\hline \multicolumn{7}{|l|}{ Number of obs. $=124$} \\
\hline $\mathrm{LR} \mathrm{chi}^{2}(14)=58.89$ & & & & & & \\
\hline Prob $>$ chi $^{2}=0.0000$ & & & & & & \\
\hline Log likelihood $=-25.340201$ & & & & & & \\
\hline Pseudo $\mathrm{R}^{2} \quad=0.5374$ & & & & & & \\
\hline
\end{tabular}

Table 9. Logistic Regression. Dependent variable: NFI

\begin{tabular}{|c|c|c|c|c|c|c|}
\hline Variables & Coef. & Std. Err. & $\mathrm{z}$ & $\mathrm{P}>\mathrm{Z}$ & \multicolumn{2}{|c|}{ [95\% Conf. Interval] } \\
\hline \multicolumn{7}{|l|}{0 (Base outcome: Both reports) } \\
\hline \multicolumn{7}{|c|}{ Dependent variable (Management Report) } \\
\hline \multicolumn{7}{|c|}{ Industry(Reference: Consumer Services) } \\
\hline Basic materials, Industry and Const. & 1.435786 & .8610301 & 1.67 & $0.095^{* * *}$ & -.2518021 & 3.123374 \\
\hline Petroleum and Energy & 0994914 & 1.239672 & 0.08 & 0.936 & 2.330221 & -2.529204 \\
\hline Consumer Services & .1593572 & .8351008 & 0.19 & 0.849 & -1.47741 & 1.796125 \\
\hline Financial Services and Real Estate & .5227982 & 1.153599 & 0.45 & 0.650 & -1.738214 & 2.78381 \\
\hline Technology and Telecomm. & 1.389667 & 1.10888 & 1.25 & 0.210 & -.7836979 & 3.563032 \\
\hline IBEX-35 & .2635234 & .8356674 & 0.32 & 0.752 & -1.374355 & 1.901401 \\
\hline Sustainability Committee & -.2044778 & .7027481 & -0.29 & 0.771 & -1.581839 & 1.172883 \\
\hline GRI & -1.501417 & .838238 & -1.79 & $0.073^{* * *}$ & -3.144333 & .1414993 \\
\hline Assurance & .2548957 & .8188547 & -0.31 & 0.756 & -1.859821 & 1.35003 \\
\hline Size & -.0847903 & .2263771 & -0.37 & 0.708 & -.5284812 & .3589007 \\
\hline ROA & 7.248872 & 4.340117 & 1.67 & $0.095^{* * *}$ & -1.257602 & 15.75535 \\
\hline Leverage & 1.021723 & 1.154303 & 0.89 & 0.376 & -1.240669 & 3.284115 \\
\hline Current Ratio & .0979116 & .1058912 & 0.92 & 0.355 & -.1096313 & .3054545 \\
\hline \multicolumn{7}{|c|}{ Dependent variable (Sustainability Report) } \\
\hline \multicolumn{7}{|c|}{ Industry(Reference: Consumer Services) } \\
\hline Basic materials, Industry and Const. & 2.497879 & 1.190841 & 2.10 & 0.128 & .1638739 & 4.831885 \\
\hline Petroleum and Energy & 4.162319 & 1.558982 & 2.67 & $0.008^{*}$ & 1.10677 & 7.217868 \\
\hline Consumer Services & 1.667865 & 1.095218 & 1.52 & $0.036^{* *}$ & -.4787227 & 3.814453 \\
\hline Financial Services and Real Estate & 4.356147 & 1.422019 & 3.06 & $0.002^{*}$ & 1.569041 & 7.143252 \\
\hline Technology and Telecomm. & 2.156641 & 1.694057 & 1.27 & 0.203 & -1.163649 & 5.476932 \\
\hline IBEX-35 & .830884 & 1.185213 & 0.70 & 0.483 & -1.49209 & 3.153858 \\
\hline Sustainability Committee & .5429894 & .87766 & 0.62 & $0.039^{* *}$ & -1.177193 & 2.263171 \\
\hline GRI & .5291399 & 1.054267 & 0.50 & 0.616 & -1.537185 & 2.595464 \\
\hline Assurance & -1.977092 & 1.068989 & -1.85 & $0.064^{* * *}$ & -4.072272 & .1180883 \\
\hline Size & .6517978 & .313667 & -2.08 & $0.038^{* *}$ & -1.266574 & -.0370216 \\
\hline ROA & 9.744913 & 4.721649 & 2.06 & 0.536 & .4906501 & 18.99918 \\
\hline Leverage & -1.626288 & 1.756987 & -0.93 & 0.355 & -5.069921 & 1.817344 \\
\hline Current Ratio & .0259414 & .1318934 & 0.20 & 0.844 & -.2325649 & .2844478 \\
\hline \multicolumn{7}{|l|}{${ }^{*} 1 \%^{* *} 5 \%{ }^{* * *} 10 \%$} \\
\hline \multicolumn{7}{|l|}{ Number of obs. $=104$} \\
\hline $\operatorname{LR~chi~}^{2}(39)=48.45$ & & & & & & \\
\hline Prob $>$ chi $^{2}=0.0000$ & & & & & & \\
\hline Log likelihood $=-85.066$ & & & & & & \\
\hline Pseudo $^{2} \quad=0.2217$ & & & & & & \\
\hline
\end{tabular}


Table 10. Descriptive - Continuous Variables

\begin{tabular}{|c|c|c|c|c|c|c|c|c|c|c|}
\hline & \multicolumn{2}{|c|}{ PAGES } & \multicolumn{2}{|c|}{ PHOTOS } & \multicolumn{2}{|c|}{ GRAPHICS } & \multicolumn{2}{|c|}{ TABLES } & \multicolumn{2}{|c|}{ INFOGRAPHICS } \\
\hline & MR & SR & MR & SR & MR & SR & MR & SR & MR & SR \\
\hline $\mathrm{N}$ & 79 & 54 & 79 & 54 & 79 & 54 & 79 & 54 & 79 & 54 \\
\hline Mean Rank & 51.69 & 89.40 & 46.69 & 92.32 & 51.87 & 89.13 & 52.90 & 88.50 & 52.75 & 87.85 \\
\hline Sum of Ranks & 4083.5 & 4827.5 & 3925.5 & 4985.5 & 4098.0 & 4813.0 & 4132.0 & 4779.0 & 4167.0 & 4744.0 \\
\hline Mann-Whitney U & \multicolumn{2}{|c|}{923.500} & \multicolumn{2}{|c|}{765.500} & \multicolumn{2}{|c|}{938.000} & \multicolumn{2}{|c|}{972.000} & \multicolumn{2}{|c|}{1007.000} \\
\hline Wilcoxon W & \multicolumn{2}{|c|}{4083.500} & \multicolumn{2}{|c|}{3925.500} & \multicolumn{2}{|c|}{4098.000} & \multicolumn{2}{|c|}{4132.000} & \multicolumn{2}{|c|}{4167.000} \\
\hline $\mathrm{Z}$ & \multicolumn{2}{|c|}{-5.542} & \multicolumn{2}{|c|}{-7.013} & \multicolumn{2}{|c|}{-5.549} & \multicolumn{2}{|c|}{-5.325} & \multicolumn{2}{|c|}{5.388} \\
\hline Asymp. Sig. (2-tailed) & \multicolumn{2}{|c|}{$.000^{*}$} & \multicolumn{2}{|c|}{$.000^{*}$} & \multicolumn{2}{|c|}{$.000^{*}$} & \multicolumn{2}{|c|}{$.000^{*}$} & \multicolumn{2}{|c|}{$.000^{*}$} \\
\hline
\end{tabular}

ies that published NFI in a MR, in a SR or in both formats; the independent variables are the characteristics of the company. In this analysis, we took the companies using both reports as the reference value. The parameter estimated indicates the probability ratio with respect to the latter category. The results obtained show that the model presents a good fit, with Prob $>\mathrm{chi}^{2}$ significant and pseudo $\mathrm{R}^{2}=0.2217$.

With respect to how these companies reported NFI, our results show that the companies in the basic materials, industry and construction sectors are more likely to publish their NFI in a MR ( $\beta: 1.435786, \mathrm{P}>\mathrm{z}: 0.095)$. In addition, companies that do not follow the GRI standards are more likely to use a MR ( $\beta$ : - $1.501417, \mathrm{P}>\mathrm{z}$ : 0.073). Moreover, profitability is significantly and positively related to NFI disclosure in a $\operatorname{MR}(\beta: 7.248872, \mathrm{P}>\mathrm{z}$ : 0.095). In contrast, the companies operating in the petroleum and energy $(\beta: 4.162319, \mathrm{p}>\mathrm{z}$ : $0.008)$, consumer services $(\beta: 1.667865, \mathrm{p}>\mathrm{z}: 0.036)$ and financial services and real estate $(\beta: 4.356147, \mathrm{P}>\mathrm{z}: 0.002)$ sectors are more likely to publish NFI in a SR. Moreover, the creation of a sustainability committee is positively associated with the decision to publish NFI in a SR $(\beta: .5429894, \mathrm{P}>\mathrm{z}$ : 0.039). NFI disclosure in a SR is negatively associated with assurance $(\beta:-1.977092, \mathrm{P}>\mathrm{z}$ : 0.064). Finally, the size of the company is also associated with NFI publication in a SR ( $\beta$ : .6517978, $\mathrm{P}>\mathrm{z}$ : 0.038).

The final aspect of our analysis is to determine the differences between MRs and SRs in terms of content. In this respect, the SRs have more pages, photos, graphics, tables and infographics than the MRs, and according to the results of the Mann-Whitney U test and the Kruskal-Wallis test, these differences are significant (see Table 10).

\section{Conclusions}

The European 2020 strategy consolidates transparency as a fundamental principle, making this a priority area of action within the Community's legislative policy. Directive 2014/95/EU on the disclosure of NFI and on diversity is a major reference in terms of corporate information disclosure, and creates a new scenario of business transparency in Europe, requiring PIEs to report on the social, environmental and governance impacts of their activities.

Before the transposition of the EU Directive, Spain was already committed to corporate transparency, and many large companies published online reports in line with GRI guidelines. Thus, in the 2015 CDP Global Climate Change Report, Spanish companies were ranked first in the reporting of environmental impacts and remedial activities.

The main aim of this paper is to analyse the NFI disclosed by Spanish listed companies and to determine the reporting strategies used in this process, in the understanding that the way in which companies communicate is an essential element in the provision of this information and in companies' engage- ment with their stakeholders. The paper is based on the legitimacy and stakeholders' theories. Academics notably used these theories because they explain the importance of a better social disclosure practice. From the perspective of the legitimacy theory, the paper shows the NFI disclosure of the companies analysed within a socially constructed system of values and rules. From the perspective of the stakeholder's theory, the paper shows the management actions that are focused on improving stakeholderst' interests towards the organisation by pointing out their needs and expectations.

Our empirical research shows that some Spanish companies still fail to disclose NFI. In contrast, those most likely to comply with information disclosure obligations are large companies in the financial services and real estate sectors. This conclusion shows that, despite disclosure of NFI is mandatory since the implementation of the EU Directive, the decision to disclose this information could be explained by the legitimacy and stakeholder theories. Thus, large companies would be more prone to disclose NFI because of their higher political visibility and their greater pressure from stakeholders. Meanwhile, companies from the financial services and real estate sectors would be more likely to reveal NFI, since they operate in 'socially-sensitive sectors', that is, sectors with high social impact (Seguí-Mas et al., 2018), and consequently, they need to show their legitimate behaviour.

Our study also analyses the stakeholder information strategy, the so-called "one-way symmetric" strategy, that companies follow to communicate their NFI. The results reveal that larger companies that operate in the petroleum and energy, consumer services, and financial services and real estate sectors, and have established a sustainability committee are more likely to disclose this information in a SR. This conclusion means that the strategies followed by these companies to disclose NFI address to a broader public. On the other hand, companies that are more profitable, and operate in the basic materials, industry and construction sectors more often publish NFI in a MR. The meaning of this conclusion is that the strategies of these companies to publish NFI focus on investors. We also found that companies that do not follow the GRI standards are more likely to reveal NFI in a MR. Furthermore, the MRs and SRs considered present significant differences regarding NFI presentation. Thus, the quantity of photos, graphics, tables and infographics provided is considerably higher in the SRs than in the MRs. In this line, the decision to disclose NFI in a MR or SR and the content of these reports could be explained by the stakeholder theory, since companies from different sectors, with certain characteristics (profitability, size...), and therefore, with different stakeholders, present different types of reports and contents. Hence, the way of communicating NFI responds to the interests and pressure of stakeholders.

With regard to the outcomes in situations of mandatory compliance, our results are in line with Sierra-García et al. (2018), who found that the business sector influence IBEX- 
35 companies to issue NFI. As regards the outcomes in situations of voluntary compliance, our results agree previous studies that also found that the business sector in which companies operate is an important determinant of a company's decision to disclose NFI (Brammer \& Pavelin 2008; Fortanier et al., 2011; among others). Our results are also consistent with Simnett et al. (2009) who found that large companies and those from the financial services sector are more likely to publish NFI.

This study presents certain limitations. Firstly, the sample is very small, composed of only 124 companies, and therefore we cannot generalise the results obtained. In future research, we will expand the scope of our analysis to include companies in other EU countries. Secondly, 2018 was the first year during which NFI disclosure was mandatory; consequently, companies might not have had a sufficient preparation for this. In future research, we will obtain data both for the year prior to the legislation and for the two years after its implementation.

In our opinion, the present study is timely and relevant. The promulgation of Act 11/2018 heightens the relevance of the present study, since the restricted period of the study data analysed highlights the effects of a transitory situation between non-mandatory publication of NFI and the requirements set out in the new legislation.

For academics, this research contributes to an emerging body of literature seeking to understand how and why companies disclose NFI in a mandatory context, such as that found in Spain. From a managerial perspective, NFI is unquestionably a chance to signal the company's commitment to sustainability and thus to enhance its accountability to stakeholders. This research may also be of interest to regulators, concerning "where" NFI should be published and possibly reducing the duplication of information across different documents.

\section{Funding}

The authors gratefully acknowledge financial support from the Ministerio de Ciencia, Innovación y Universidades (RTI2018-093423-BI00).

\section{Conflict of interests}

The authors declare no conflict of interests.

\section{References}

AccountAbility (2008a). AA1000 Accountability Principles Standard 2008. London: AccountAbility.

AccountAbility (2008b). AA1000 Assurance Standard 2008. London: AccountAbility.

Ali, W., Frynas, J.G., \& Mahmood, Z. (2017). Determinants of corporate social responsibility (CSR) disclosure in developed and developing countries: a literature review. Corporate Social Responsibility and Environmental Management, 24(4), 273-294. https://doi.org/10.1002/ csr. 1410

Archel, P., Husillos, J., Larrinaga, C., \& Spence, C. (2009). Social disclosure, legitimacy theory and the role of the state. Accounting, Auditing \& Accountability Journal, 22(8), 1284-1307. https://doi.org/10.1108/
09513570910999319

Archel, P., Husillos, J., \& Spence, C. (2011). The institutionalization of unaccountability: Loading the dice of corporate social responsibility discourse. Accounting, Organizations and Society, 36, 327-334. https://doi.org/10.1016/j.aos. 2011.06.003

Aureli, S., Salvatori, F., \& Magnaghi, E. (2020). A CountryComparative Analysis of the Transposition of the EU NonFinancial Directive: An Institutional Approach. Accounting, Economics, and Law, 10(2), 1-30. https://doi.org/10. 1515/ael-2018-0047.

Bartlett, J.L., \& Devin, B. (2011). Management, communication and corporate social responsibility. In O. Ihlen, J.L. Bartlett, \& S. May (Eds.) The Handbook of Communication and Corporate Social Responsibility (pp. 47-66). Oxford: Wiley Blackwell.

Block, J. H., Stiglbauer, M., Kühn, A. L., \& Wagner, D. (2015). Corporate social responsibility communication of German family firms: A content analysis. uwf UmweltWirtschaftsForum, 23(4), 251-257.

Brammer, S., \& Pavelin, S. (2008). Factors influencing the quality of corporate environmental disclosure. Business Strategy and the Environment, 17 (2), 120-136. https:// doi.org/10.1002/bse.506

Branco, M.C., \& Rodrigues, L.L. (2008). Social responsibility disclosure: a study of proxies for the public visibility of Portuguese banks. British Accounting Review, 40, 161181. http://dx.doi.org/10.1108/13563280610680821

Brennan, N.M., Merkl-Davies, D.M., \& Beelitz, A. (2013). Dialogism in corporate social responsibility communications: conceptualizing verbal interactions between organizations and their audiences. Journal of Business Ethics, 15 (4), 665-679. https://doi.org/10.1007/ s10551-013-1825-9

Boiral, O., Heras Saizarbitoria, I., Brotherton, M.C., \& Bernard, J. (2019). Ethical issues in the assurance of sustainability reports: Perspectives from assurance providers. Journal of Business Ethics, 159, 1111-1125. https://doi. org/10.1007/s10551-018-3840-3.

CDP (2015). CDP Global Climate Change Report 2015. CDP.

Cho, C.H., Michelon, G., Patten, D.M., \& Roberts, R.W. (2014). CSR report assurance in the USA: an empirical investigation of determinants and effects. Sustainability Accounting, Management and Policy Journal, 5(2), 130-148. https://doi.org/10.1108/SAMPJ-01-2014-0003

Cho, C.H., Michelon, G., Patten, D.M., \& Roberts, R.W. (2015). CSR disclosure: the more things change...? Accounting, Auditing \& Accountability Journal, 28(1), 14-35. https://doi.org/10.1108/AAAJ-12-2013-1549

Coombs, W.T., \& Holladay, S. J. (2012). Managing corporate social responsibility: A communication approach. Malden, MA: Wiley Blackwell.

Cormier, D., \& Magnan, M. (2003). Environmental reporting management: a continental European perspective. Journal of Accounting and Public Policy, 22, 43-62. https: //doi.org/10.1016/S0278-4254(02)00085-6

Correa-García, J., García-Benau, M.A., \& García-Meca. E. (2018). CSR communication strategies of Colombian business groups: An analysis of corporate reports. Sustainability, 10, 1062. https://doi.org/10.3390/ su10051602

Davis, G. \& Searcy, C. (2010). A review of Canadian corporate sustainable development reports. Journal of Global Responsibility, 1 (2), 316-329. https://doi.org/10.1108/ 20412561011079425

Dawkins, J. (2004). Corporate responsibility. The 
communication challenge. Journal of Communication Management, 9, 108-119. https://doi.org/10.1108/ 13632540510621362

Deegan, C. (2002). The legitimating effect of social and environmental disclosures: a theoretical foundation. Accounting, Auditing and Accountability Journal, 15, 281311. http://dx.doi.org/10.1108/09513570210435852

De Beelde, I., \& Tuybens, S. (2015). Enhancing the credibility of reporting on corporate social responsibility in Europe. Business Strategy and the Environment, 24, 190216. https://doi.org/10.1002/bse.1814

De Klerk, M., \& de Villiers, C. (2012). The value relevance of corporate responsibility reporting: South African evidence. Meditari Accountancy Research, 20(1), 21-38. https://doi.org/10.1108/10222521211234200

De Villiers, C., \& Van Staden, C.J. (2011). Where firms choose to disclose voluntary environmental information. Journal of Accounting and Public Policy, 30(6), 504-525. https://doi.org/10.1016/j.jaccpubpol.2011.03.005

Dhanesh, G. S. (2015). Why corporate social responsibility? An analysis of drivers of CSR in India. Management Communication Quarterly, 29(1), 114-129.

Dowling, J., \& Pfeffer, J. (1975). Organizational Legitimacy: Social Values and Organizational Behavior. Pacific Sociological Review, 18(1), 122-136.

EU (2003). Directive 2003/51/EC of the European Parliament and of the Council of 18 June 2003 amending Directives 78/660/EEC, 83/349/EEC, 86/635/EEC and $91 / 674 /$ EEC on the annual and consolidated accounts of certain types of companies, banks and other financial institutions and insurance undertakings.

EU (2011). Green Paper. Promoting a European Framework for Corporate Social Responsibility. Commission of the European Communities. Brussels.

EU (2013). Directive 2013/34/EU of the European Parliament and of the Council of 26 June 2013 on the annual financial statements, consolidated financial statements annual and related reports of certain types of undertakings, amending Directive 2006/43/EC of the European Parliament and of the Council and repealing Council Directives 78/660/EEC and 83/349/EEC.

EU (2014a). Directiva 2014/95/UE del Parlamento Europeo y del Consejo, de 22 de octubre de 2014, por la que se modifica la Directiva 2013/34/UE en lo que respecta a la divulgación de información no financiera e información sobre diversidad por parte de determinadas grandes empresas y determinados grupos. Madrid: Ministerio de Economía.

EU (2014b). Disclosure of non-financial information: Europet's largest companies to be more transparent on social and environmental issues. Statement by the Commission on 29.09.2014.

EU (2017). Communication from the Commission guidelines on non-financial reporting (methodology for reporting non-financial information) (2017/c 215/01).

Fathi, J. (2013). The determinants of the quality of financial information disclosed by French listed companies. Mediterranean Journal of Social Sciences, 4 (2), 319-336. http://dx.doi.org/10.5901/mjss.2013.v4n2p319

Fernandez-Feijoo, B., Romero, S. \& Ruiz, S. (2014). Effect of stakeholders' pressure on transparency of sustainability reports within the GRI framework. Journal of Business Ethics, 122, 53-63. https://doi.org/10.1007/ s10551-013-1748-5

Fernando, S., \& Lawrence, S., (2014). A theoretical framework for CSR practices: integrating legitimacy theory, stakeholder theory and institutional theory. Journal of Theoretical Accounting Research, 10(1), 149-178.

FernandezFeijoo, B., Romero, S., \& Ruiz, S. (2015). Multilevel approach to sustainability report assurance decisions. Australian Accounting Review, 25(4), 346-358.

Fonseca, A. (2010). How credible are mining corporations' sustainability reports? A critical analysis of external assurance under the requirements of the international council on mining and metal. Corporate Social Responsibility and Environmental Management, 17 (6), 355-370. http: //dx.doi.org/10.1002/csr.230

Fortanier, F., Kolk, A., \& Pinkse, J. (2011). Harmonization in CSR reporting: MNEs and global CSR standards. Management International Review, 51, 665-696. https://doi.org/ 10.1007/s11575-011-0089-9

Freeman, R.E. (1984). Strategic Management: A stakeholder approach. New York: Cambridge University Press.

Gantiowati, E., \& Agustine, K.F. (2017). Firm's Characteristics and CSR Disclosure, Indonesia and Malaysia Cases. Review of Integrative Business and Economics Research, 6(3), 131-145.

García-Sánchez, I.M., Rodriguez-Dominguez, L., \& GallegoAlvarez, I. (2011). Corporate governance and strategic information on the internet. Accounting, Auditing and Accountability Journal, 24(4), 471-501. https://doi.org/10. 1108/09513571111133063

Garrido-Miralles, P., Zorio, A., \& García-Benau, M.A. (2016). Sustainable development, stakeholder engagement and analyst forecasts' accuracy: positive evidence from the Spanish setting. [Sustainable Development], 24(2). https: //doi.org/10.1002/sd.1607

GRI North America (2014). Trends in External Assurance of Sustainability Reports: Update on the US.

Gürtürk, A., \& Hahn, R. (2016). An empirical assessment of assurance statements in sustainability reports: Smoke screens or enlightening information? Journal of Cleaner Production, 136, 30-41. https://doi.org/10. 1016/j.jclepro.2015.09.089

Haniffa, R.M., \& Cooke, T.E. (2005). The impact of culture and governance on corporate social reporting. Journal of Accounting and Public Policy, 24, 391-430. https://doi. org/10.1016/j.jaccpubpol.2005.06.001

Hernández, J. (2017). Pocas novedades en la transposición de la Directiva de Información no financiera. Blog KPMG Responsabilidad empresarial. Available at http://www.kpmgresponsabilidadempresarial.es/ pocas $\% 2$ dnovedades $\% 2$ den $\% 2$ dla $\% 2$ dtransposicion $\%$ 2dde $\% 2$ dla $\% 2$ ddirectiva $\% 2$ dde $\% 2$ dinformacion $\%$ 2dno\%2dfinanciera/

Hossain, M., Islam, M.T., Momin, M.A., Nahar, S., \& Alam, M.S. (2018). Understanding communication of sustainability reporting: application of symbolic convergence theory (SCT). Journal of Business Ethics, 1-24. https: //doi.org/10.1007/s10551-018-3874-6

Husted, B. W. (2015). Corporate social responsibility practice from 1800-1914: past initiatives and current debates. Business Ethics Quarterly, 25(1), 1-17. https://doi.org/ 10.1017/beq.2014.1

IAASB (2013). ISAE 3000 (Revised), Assurance Engagements Other than Audits or Reviews of Historical Financial Information. New York: International Federation of Accountants.

Investis (2015). Social Media for corporate communications: a review of corporate social media use in the US and in the UK. Investis, New York.

Junior, R., Best, P., \& Cotter, J. (2014). Sustainability re- 
porting and assurance: A historical analysis on a worldwide phenomenon. Journal of Business Ethics, 120, 1-11. https://doi.org/10.1007/s10551-013-1637-y

Kamil, A., \& Herusetya, A. (2012). Pengaruh Karakteristik Perusahaan terhadap Luas Pengungkapan Kegiatan Corporate Social responsibility. Media Riset Akuntansi, 2, 117.

Kend, M. (2015). Governance, firm-level characteristics and their impact on the client's voluntary sustainability disclosures and assurance decisions Sustainability Accounting, Management and Policy Journal, 6, 54-78. https: //doi.org/10.1108/SAMPJ-12-2013-0061

Kent, P., \& Monem, R., (2008). What drives TBL reporting: good governance or threat to legitimacy? Australian Accounting Review, 18, 297-309.

Khan, H.U.Z. (2010). The Effect of Corporate Governance Elements on Corporate Social Responsibility (CSR) Reporting Empirical Evidence from Private Commercial Banks of Bangladesh. International Journal of Law and Management, 52, 82-109.

Kim, J., \& Im, C. (2017). Study on Corporate Social Responsibility: Focus on tax avoidance and financial ratio analysis. Sustainability, 9, 1710. https://doi.org/10.3390/ su9101710

Kollat, J., \& Farache, F. (2017). Achieving consumer trust on twitter via CSR communication. Journal of Consumer Marketing, 34(6), 505-514. https://doi.org/10.1108/ JCM-03-2017-2127

Kolk, A. (2003). Trends in sustainability reporting by the Fortune Global 250. Business Strategy and the Environment, 12, 279-291. https://doi.org/10.1002/bse.370

Kolk, A., \& Perego, P. (2010). Determinants of the adoption of sustainability assurance statements: An international investigation. Business Strategy and the Environment, 19, 182-198. https://doi.org/10.1002/bse.643

KPMG (2011). KPMG international survey of corporate responsibility reporting 2011. London: KPMG.

KPMG (2015). The KPMG Survey of Corporate Responsibility Reporting 2015. London: KPMG.

KPMG (2017). The KPMG Corporate Responsibility Reporting 2017. London: KPMG.

Lanis, R., \& Richardson, G. (2012). Corporate social responsibility and tax aggressiveness: A test of legitimacy theory. Accounting, Auditing and Accountability Journal, 26, 75100. https://doi.org/10.1108/09513571311285621

Law Chapple, L., Chen, Z., \& Zhang, Y. (2017). Sustainability Committee Effectiveness and CSR Assurance. Available online: https://ssrn.com/abstract=2967165 (accessed on 12 April 2018).

Liao, P. C., Xia, N. N., Wu, C. L., Zhang, X. L., \& Yeh, J. L. (2017). Communicating the corporate social responsibility (CSR) of international contractors: Content analysis of CSR reporting. Journal of Cleaner Production, 156, 327-336.

Lim, J.S., \& Greenwood, C.A. (2017). Communicating corporate social responsibility (CSR): Stakeholder responsiveness and engagement strategy to achieve CSR goals. Public Relations Review, 43 (4), 768-776. https://doi.org/ 10.1016/j.pubrev.2017.06.007

Litt, E., Spottswood, E., Birnholtz, J., Hancock, J.T., Smith, M.E., \& Reynolds, L. (2014). Awkward encounters of another kind. Collective self-presentation and face threat on Facebook. In proceedings of the $17^{\text {th }}$ ACM conference on computer supported cooperative work \& social computing, pp 449-460.

Luque-Vilchez, M., \& Larrinaga, C. (2016). Reporting models do not translate well: Failing to regulate CSR reporting in Spain. Social and Environmental Accountability Journal, 36(1), 56-75. https://doi.org/10.1080/0969160X.2016. 1149301

Manetti, G., \& Becatti, L. (2009). Assurance services for sustainability reports: standards and empirical evidence. Journal of Business Ethics, 87(1), 289-298.

Maroun, W. (2017). Assuring the integrated report: Insights and recommendations from auditors and preparers. The British Accounting Review, 49(3), 329-346. https://doi. org/10.1016/j.bar.2017.03.003

Martínez Ferrero, J., \& García Sánchez, M.I. (2017). Coercive, Normative and Mimetic Isomorphism as Determinants of the Voluntary Assurance of Sustainability Reports. International Business Review, 26, 102-118.

Matsumoto, D., Pronk, M., \& Roelofsen, E. (2011). What makes conference calls useful? The information content of managerst' presentations and analystst' discussion sessions. The Accounting Review, 86(4), 1383-1414. https: //doi.org/10.2308/accr-10034

Matuszak, L., \& Rozanska, E. (2017). CSR disclosure in Polish-listed companies in the light of Directive 2014/95/EU requirements: Empirical evidence. Sustainability, 9, 2304. https://doi.org/10.3390/su9122304

May, S. (2011). Organizational communication and corporate social responsibility. In Ihlen, O., Bartlett, J.L. \& May, S. (Eds.), The Handbook of Communication and Corporate Social Responsibility: 87-109. Oxford: Wiley Blackwell.

Melis, A., Gaia, S., \& Carta, S. (2015). Directors' remuneration: A comparison of Italian and UK nonfinancial listed firms' disclosure. The British Accounting Review, 47, 6684. https://doi.org/10.1016/j.bar.2014.08.004

Merkl-Davies, D.M., \& Brennan, N.M. (2017). A theoretical framework of external accounting communication: research perspectives, traditions and theories. Accounting, Auditing and Accountability Journal, 30(2), 433-469. https://doi.org/10.1108/AAAJ-04-2015-2039

Mio, C., \& Venturelli, A. (2013). Non-financial information about sustainable development and environmental policy in the annual reports of listed companies: evidence from Italy and the UK. Corporate Social Responsibility and Environmental Management, 20(6), 340-358. https://doi.org/10.1002/csr.129

Mion, G., \& Loza-Adaui, C.R. (2019). Mandatory Nonfinancial Disclosure and Its Consequences on the Sustainability Reporting Quality of Italian and German Companies. Sustainability, 11, 4612; doi:10.3390/su11174612.

Miska, C.H., Stahl, G.S., \& Mendenhall, M.E. (2013). Intercultural competencies as antecedents of responsible global leadership. European Journal of International Management, 7(5), 550-569. https://doi.org/\%5B10.1504/ EJIM.2013.056477\%5D

Mock, T.J., Rao, S., \& Srivastava, R.P. (2013). The development of worldwide sustainability reporting assurance. Australian Accounting Review, 23, 280-294. https://doi. org/10.1111/auar.12013

Moneva, J.M., \& Llena, F. (1996). Análisis de la información sobre responsabilidad social en las empresas industriales que cotizan en bolsa. Revista Española de Financiación y Contabilidad, 25(87), 361-401. https://www.jstor.org/ stable/42781210

Morhardt, J.E. (2010). Corporate social responsibility and sustainability reporting on the Internet. Business Strategy and the Environment, 19, 436-452. https://doi.org/10. 1002/bse.657

Morsing, M., \& Schultz, M. (2006). Corporate social re- 
sponsibility communication: stakeholder information, response and involvement strategies. Business Ethics: A European Review, 15(4), 323-338. https://doi.org/10. $1111 / \mathrm{j} .1467-8608.2006 .00460 . x$

Moser, D.V., \& Martin, P.R. (2012). A broader perspective on corporate social responsibility research in accounting. The Accounting Review, 87, 797-806. https://doi.org/10. 2308/accr-10257

Muhammad, A., Cory, S., Paulo, S., \& David, K. (2013). A review of Dutch corporate sustainable development reports. Corporate Social Responsibility and Environmental Management, 20(6), 321-339. https://doi.org/10.1002/ csr. 1284

Muttakin, M.B., \& Khan, A. (2014). Determinants of corporate social disclosure: empirical evidence from Bangladesh. Advances in Accounting, 30(1), 168-175. https://doi.org/10.1016/j.adiac.2014.03.005

Nurunnabi, M., Hossain, M., \& Hossain, M. (2011). Intellectual capital reporting in a South Asian country: evidence from Bangladesh. Journal of Human Resource Costing \& Accounting, 15(3), 196-233. https://doi.org/10.1108/ 14013381111178587

O’Dwyer, B., Owen, D., \& Unerman, J. (2011). Seeking legitimacy for new assurance forms: The case of assurance on sustainability reporting. Accounting, Organizations and Society, 36, 31-52. https://doi.org/10.1016/j.aos.2011. 01.002.

Oliver, C. (1991). Strategic responses to institutional processes. Academy of management review, 16(1), 145-179.

Organization for Economic Co-operation and Development (2011). OECD Guidelines for Multinational Enterprises. Available at http://mneguidelines.oecd.org

Ortiz Martínez, E., \& Marín Hernández, S. (2014). Global Reporting Initiative (GRI) as recognized guidelines for sustainability reporting by Spanish companies on the IBEX 35: Homogeneity in their framework and added value in the relationship with financial entities. Intangible capital, 10(5), 855-872.

Ortiz, E., \& Marín, S. (2017). Comunicar información no financiera e IDE por regiones. Revista de Globalización, Competitividad y Gobernabilidad, 11(1), 94-111. https:// doi.org/\%5B10.3232\%5D/GCG.[2017].V11.N[1.04]

Patten, D.M. (2002). The relation between environmental performance and environmental disclosure: A research note. Accounting: Organizations and Society, 27, 763-773. https://doi.org/10.1016/S0361-3682(02)00028-4

Prado-Lorenzo, J., Gallego-Alvarez, I., \& Garcia-Sanchez, I. M. (2009). Stakeholder engagement and corporate social responsibility reporting: The ownership structure effect. Corporate Social Responsibility and Environmental Management, 16(2), 94-107. https://doi.org/10.1002/ csr. 189

Real Decreto-ley 18/2017, de 24 de noviembre, por el que se modifican el Código de Comercio, el texto refundido de la Ley de Sociedades de Capital aprobado por el Real Decreto Legislativo 1/2010, de 2 de julio, y la Ley 22/2015, de 20 de julio, de Auditoría de Cuentas, en materia de información no financiera y diversidad (BOE 25 noviembre 2017).

Reverte, C. (2009). Determinants of corporate social responsibility disclosure ratings by Spanish listed firms. Journal of business ethics, 88(2), 351-366.

Rodrigue, M., Magnan, M., \& Cho, C.H. (2013). Is environmental governance substantive or symbolic? An empirical investigation. Journal of Business Ethics, 114, 107-
129, https://doi.org/10.1007/s10551-012-1331-5

Rodríguez-Gutiérrez, P., Fuentes-García, F.J., \& SánchezCañizares, S.M. (2013). Transparency in social disclosure in financial institutions through Spanish CSR reports in the context of crisis. Universia Business Review, 2, 84-107. https://www.redalyc.org/pdf/433/43328033005.pdf

Seguí-Mas, E., Polo-Garrido, F., \& Bollas-Araya, H.M. (2018). Sustainability Assurance in Socially-Sensitive Sectors: A Worldwide Analysis of the Financial Services Industry. Sustainability, 10, 2777. https://doi.org/10. 3390/su10082777.

Sierra-García, L., García-Benau, M.A., \& Bollas-Araya, H.M. (2018). Empirical analysis of non-financial reporting by Spanish companies. Administrative Sciences, 8(3). https: //doi.org/10.3390/admsci8030029

Simnett, R., Vanstraelen, A., \& Chua, W. (2009). Assurance on sustainability reports: An international comparison. The Accounting Review, 84, 937-967. https://doi.org/10. 2308/accr.2009.84.3.937

Spanish Ministry of Economy (2011). Law 2/2011 of March 4, 2011, on Sustainable Economy (BOE March 3, 2011). Madrid: Spain.

Spanish Ministry of Employment and Social Security (2014). Spanish strategy on companiest' corporate social responsibility practices 2014-2020. Madrid: Spain.

Stanny, E., \& Ely, K. (2008). Corporate environmental disclosures about the effects of climate change. Corporate Social Responsibility and Environmental Management, 15, 338-348. https://doi.org/10.1002/csr.175

Suárez-Rico, Y. M., Gómez-Villegas, M., \& García-Benau, M. A. (2018). Exploring Twitter for CSR disclosure: Influence of CEO and firm characteristics in Latin American companies. Sustainability, 10(8), 2617.

Sweeney, L., \& Coughlan, J. (2008). Do different industries report corporate social responsibility differently? An investigation through the lens of stakeholder theory. Journal of Marketing Communications, 14(2), 113-124.

Tagesson, T., Blank, V., Broberg, P., \& Collin, S. (2009). What explains the extent and content of social and environmental disclosures on corporate websites: A study of social and environmental reporting in Swedish listed corporations. Corporate Social Responsibility and Environmental Management, 16, 352-364. https://doi.org/10.1002/csr. 194

Tarquinio, L., Raucci, D., \& Benedetti, R. (2018). An investigation of global reporting initiative performance indicators in corporate sustainability reports: Greek, Italian and Spanish evidence. Sustainability, 10(4), 897-915. https://doi.org/10.3390/su10040897

Tiron-Tudor, A., Nistor, C.S., tefnescu, C.A., \& Zanellato, G. (2019). Encompassing non-financial reporting in a coercitive framework for enhancing social responsibility: Romanian listed companies' case. Amfiteatru Economic, 21(52), 2-16. https://doi.org/10.24818/EA/2019/52/ 590

Venturelli, A., Simona Costa, F.C., Leopizzi, R., \& Pizzi, S. (2017). Directive 2014/95/EU: Are Italian companies already compliant? Sustainability, 9, 1385. https://doi. org/10.3390/su9081385

Wyatt, A., \& Frick, H. (2010). Accounting for investments in human capital: a review. Australian Accounting Review, 20(3), 265-273. https://doi.org/10.1111/j.1835-2561. 2010.00104.X

Yang, J.H., \& Liu, S. (2017). Accounting narratives and impression management on social media. Accounting and Business Research, 47(6), 673-694. https://doi.org/10. 
1080/00014788.2017.1322936

Young, A.L., \& Quan-Haase, A. (2013). Privacy protection strategies on facebook: the internet privacy paradox revisited. Information, Communication \& Society, 16 (4), 479500. https://doi.org/10.1080/1369118X.2013.777757

$\mathrm{Yu}, \mathrm{X}$. (2008). Impacts of corporate code of conduct on labor standards: a case study of Reebokt's athletic footwear supplier factory in China. Journal of Business Ethics, 81(3), 513-529. https://doi.org/10.1007/s10551-007-9521-2

Ziek, P. (2009). Making sense of CSR communication. Corporate Social Responsibility and Environmental Management, 16, 137-145. https://doi.org/10.1002/csr.183 